\title{
Not All Human Trafficking is Created Equal: Transnational Human Trafficking in the UK and Serbian News Media Texts- Narratological and Media Studies Approaches
}

\section{Nina Muždeka}

\begin{abstract}
This chapter investigates the representation of transnational human trafficking in news texts in English and Serbian (published between 2000-2016 and 2003-2016 respectively) by adopting contemporary narrative and media theories. The identified narrative strategies and narrative elements (pertaining to the fabula, story, and text) not only shape the news texts, but also function as a semiotic code through which reality is itself constructed. In both sets of news texts, narratives as forms of representation prioritize particular aspects of human trafficking (e.g., use of official sources), while neglecting and/or completely excluding others (e.g., roots of human trafficking). The chapter draws attention to the logic behind such mechanisms that transform information into meaningful structures and thus influence the shaping of public perception and responses to this crime.
\end{abstract}

Keywords Human trafficking $\bullet$ Media studies $\bullet$ Narrative $\bullet$ Narratology - Newsworthiness $\bullet$ Serbian news media texts $\bullet$ UK news media texts

N. Muždeka $(\bowtie)$

University of Novi Sad, Novi Sad, Serbia

e-mail: nina.muzdeka@ff.uns.ac.rs

(C) The Author(s) 2018 


\section{INTRODUCTION}

Transnational human trafficking invites debate on the role of the media as a contemporary watchdog and a forum for showcasing diverse viewpoints. To shed light on some of the mechanisms that direct the media approach to representation of human trafficking (henceforth HT), this chapter investigates the representation of HT in UK and Serbian news media, using contemporary narrative and media theories (Bal, 2009; Fulton, 2005; Jahn, 2005; Zelizer \& Allan, 2010). In this approach, HT news media texts in both languages are treated as narratives, that is, forms of representation culturally positioned to turn information into meaningful structures and thus to produce diverse meanings within different social and cultural milieus, addressing and affecting target audiences in specific ways. Narrative and media theories place emphasis on the aspects of narrative structure, construction, form, patterns, medium, and the elementary epistemology of knowing the world.

Fulton (2005) defines the relationship between text and its meaning using broadly defined poststructuralism as a theoretical approach. The basic, but often overlooked, tenet, is the fact that information (as a nonnarrative segment) does not equal news (as a narrative construct). A piece of news represents a "deliberately structured story" (Fulton, 2005, p. 219), not the fact or the truth itself (however we choose to define the concepts of "fact" and "truth"). As a deliberately created structure, a news story "translates" the initial information into meaning using narrative strategies, that is, the narrative construction. The aspects of narrative construction are analysed as a semiotic code in which not only news is created, but also so is a much more encompassing and influential structure: our whole sense of reality of the world that surrounds us, as recipients of news. Since this semiotic code contributes to the process of creating public opinion, perception, and agenda, its analysis also allows investigation into the wider ideological implications and socio-political positioning that lies behind the process of constructing and creating news. ${ }^{1}$

Narrative studies and media and communication studies identify similar aspects of narrative construction as crucial for understanding the process of news creation. Media and communication studies define "narrative" as "the organizing structure of a news story that describes in patterned ways the unfolding of public events or issues within the parameters made

${ }^{1} \mathrm{Bal}(2009$, p. 35) insists that "narratological analysis inherently serves political or ideological critique" since ideology cannot be isolated from structure. 
available by a technological medium" (Zelizer \& Allan, 2010, p. 77). As such, any news narrative "offers a fundamental epistemological way of knowing the world, involving sequence, setting, perspective, characterization, tone, and a relationship with the public" and is "differentiated both by its contents - what it says, the story or plot - and its form-how it says, the act of narration" (Zelizer \& Allan, 2010, p. 77). Using different terms but essentially the same logic, Johnson-Cartee (2005, p. 159) defines narrative as a fully developed story that includes "characters, scene descriptions, conflicts, actions with motives, [and] resolutions". What provides the structure is the narrative frame, that is, "the basic organization of the structural components used in the story" (Johnson-Cartee, 2005, p. 159). Referring to the narrative frame, other authors in the field used expressions such as "formulaic narrative construction" (Bird \& Dardenne, 1988, p. 67) and "structure of expectation" (Tannen, 1993, p. 15). Irrespective of the exact term used, the essence remains the same-what is noticed and identified is the basic schema or the prototype of organization that transforms various separate structural elements into a coherent narrative structure. Following this logic, it can be argued that what is commonly deemed as journalistic objectivity constitutes "sameness in news" ascribed to the application of a particular narrative frame, not mirroring reality (Bird \& Dardenne, 1988, p. 67).

Bal $(2009$, p. 10) defines narrative as a "cultural phenomenon" consisting of three layers: the text (synonymous with "discourse" or "surface telling", see Fulton, 2005, p. 37; cf. Genette, 1988), the story (synonymous with "plot" and "syuzhet", see Bal, 2009), and the fabula ("a series of logically and chronologically related events [...] caused or experienced by actors"-Bal, 2009, pp. 5-9). Within the analysis of a fabula, I examine the elementary choice of events that make the news. The analysis of elements of a story includes the aspects of characters (who participates?) ${ }^{2}$ and focalization (who sees the events?). ${ }^{3}$ Here I also analyse the social

${ }^{2}$ While Bal (2009, p. 92) analyses participants in the chosen events at both the level of a fabula (as "actors" or "actants", i.e., "abstract units") and the level of a story (where "actors are 'turned into' characters, placed into specific spaces with mutual symbolic and circumstantial relations"), I opted for the analysis of this element at the level of a story only in order to illustrate better their role in the construction of news as stories with a particular agenda to be promoted. Bal's $(2009$, p. 129) distinction says that "an actor in a fabula is a structural position, while a character is a complex semantic unit".

${ }^{3} \mathrm{Bal}(2009$, pp. 191-192) considers focalization to be "the most important, most penetrating, and most subtle means of manipulation" which should not be marginalized (in favour of content analysis) when analysing newspaper reports for their "hidden ideology". 
groups or individuals that are given voice in the text, by showing which of these are marked as prominent, which are placed in the background, and which are completely neglected/excluded. Within the analysis of text and narration, I investigate the structure of news texts in terms of the dissemination of information, as well as levels of narration (including frame/primary and embedded texts). The aim of the analysis of these three layers of narrative structure is to show how these narrative elements are employed regarding their role in turning information into print media discourses that portray transnational HT in UK and Serbian news media texts. Finally, I interpret the ideological positioning that is created as a result of such a narrative construction, showing how particular ideological standpoints are promoted in the news media narratives on HT.

To maintain consistency across the project, the same English language news media text corpus of sixty-seven texts was used for this analysis as in this collection's Chap. 2. For the selection of the Serbian language texts, the most extensive Serbian news media database (EBART) was used, archiving news media output since 2003. EBART archives both broadsheet and tabloid newspaper sources, of national, regional and local coverage, in both Cyrillic and Latin script. ${ }^{4}$ The average number of HT-related news texts was thirty-five per month. The core search terms used were direct translations of the search terms used for the English language corpus: human trafficking ("trgovina ljudima", "trafiking"), slavery ("ropstvo"), modern slavery ("savremeno ropstvo", "moderno ropstvo"), trafficking in human beings ("trgovina belim robljem", "trgovina ljudskim bićima", "trgovina ljudima"), forced labour ("prinudni rad", "prisilni rad"), sexual exploitation ("seksualna eksploatacija"), sex trafficking/sexual trafficking ("seks-trafiking", "seks trafiking"), and sex slave ("seksualno ropstvo", "seksualno roblje"). Articles were manually checked to ensure they were related to HT. ${ }^{5}$

${ }^{4}$ The corpus included 315 newspaper articles published in 28 different print news media: Akter, Balkan, Blic, Borba, Danas, Dnevnik, Ekonomist, Ekspres, Glas javnosti, Gradanski list, Informer, Kurir, Nacional, Narodne novine, Naše novine, Nedeljni telegraf, NIN, Novi Magazin, Pančevac, Politika, Pravda, Pregled, Press, Srpski nacional, TV novosti, Večernje novosti, Vranjske, and Vreme.

${ }^{5}$ Most notably, this kind of manual checking for relevance was done because of the high frequency of Serbian texts with the key word "trafika", which is a false friend of English "trafficking" (and denotes a newspaper booth or kiosk- a very frequent robbery target and thus a very frequent occurrence in the news). 


\section{Fabula: What to Choose for the News?}

In the interpretation of news media texts, fabula - as material which is an essential, basic layer of any narrative - is "the answer to the classic journalist's questions" (Who? What? Where? How? When? Why?) (Conboy, 2007, p. 43). Events featured in British and Serbian news texts on HT were categorized as in the following subsections.

\section{Arrests and Reports on Criminal Acts}

As the most prominent and numerous articles on HT in both UK and Serbian news print media, these cover the incidents that happened most recently. In the fabula of these texts, two events are typically featured: the act of arrest, and the criminal act perpetrated by the arrested and/or trafficked person/people. The UK press reported on a "Man seized for slavery", the discovery of illegal immigrants found in the back of a lorry, and the arrest of a man after a 26-year old Romanian victim is found by the police (The People, 2016; The Daily Star, 2016; The Guardian, 20156). In Serbian media, similar events occur: the arrest of 13 people found smuggling illegal immigrants in Vranje in June 2015, the arrest of a theme park owner suspected of keeping a slave for 4 years, the arrest of a group suspected of forcing a 16 year old girl into prostitution, and the arrest of a person suspected of selling a girl into forced marriage (Blic, 2013b; Informer, 2013, 2014; Večernje novosti, 2015b).

\section{Court Proceedings}

This group includes trials and sentences for HT-related criminal acts. Articles stemming from them also feature at least two events-those related to the court (the trial, witness statements, sentencing), and those referring to the actual HT-related crime (mentioning victims and/or circumstances of the criminal act). The UK press reported on "'Trafficked' Briton to lodge drugs death-sentence appeal" (Fearn, 2015), on the sentence of "14 years for trucker who left 58 to die" (Leonard, 2001), and a sex trafficker "convicted of rape, conspiracy to traffic and conspiracy to control prostitution" (The Sun, 2015). Similarly, in the Serbian press, some of the numerous examples

\footnotetext{
${ }^{6}$ Those news articles in which the author's name was not given are referred to by virtue of the publication.
} 
are: a criminal duo sentenced to 5 years in jail for trafficking a 19-year-old girl, a Pakistani man sentenced to 3 years for HT in Serbia, a report from the ongoing trial of a criminal group of 10 people suspected of trafficking a girl (Danas, 2004b, 2015; Večernje novosti, 2004a) and so on.

\section{Official Reports on HT}

These articles usually summarize facts and figures related to HT for a given period and country/region. The reports and studies are issued by authorities and agencies either linked to the government or to NGOs. In the UK press, articles were triggered, for example, by the publication of an EU report on HT and a Home Office report on HT (Rankin, 2016; The Times, 2007). The examples from the Serbian press include: a UN report on organized crime in South-East Europe, ASTRA anti-trafficking organization's report for 2010, and a US State Department report on HT (Blic, 2004; Pregled, 2011; Večernje novosti, 2007b).

\section{Planned Responses to HT}

These events are found in the announcements from the authorities regarding their plans to respond to HT. The UK press reported, for example, on "UK police [having been] deployed to Calais to tackle people-trafficking gangs" (Smith, 2015), "Britain to send intelligence officers to Sicily to 'disrupt' human traffickers" (Watt, Travis, \& Mason, 2015), and the Home Secretary announcing "plans for a crackdown on trafficking gangs" whilst also signing "the European Convention on Human Trafficking which commits signatories to tackling the traffickers and helping victims" (Harrison, 2007). Serbian media similarly published articles headlined "Serbia to decisively fight HT" (Nedeljni telegraf, 2008) and "Battle strategy to combat HT" (Politika, 2006) (in which government officials expand on the proposed strategies), as well as the article on signing the UN anti-trafficking protocol in 2004 (Danas, 2004a).

\section{HT-Related Public Events}

These include seminars, round tables, public lectures, film screenings, theatre performances, public campaigns, and similar events related to HT. In UK newspapers, such was the article on the slavery summit held by "Britain's top confectionery companies" (Clark, 2001). Serbian print 
media featured, for example, a conference on HT in South-East Europe, a round table organized by an OSCE mission to Serbia, the Serbian Department of Justice, and the Victimological Society of Serbia, an antiHT campaign launched by "Beosupport" (NGO), and a conference held to publicize a Serbian film on HT (Danas, 2005; Glas javnosti, 2004a; Politika, 2004; Pravda, 2010).

\section{Personal Experience/Victim Targeting and Victim Profiling}

The UK print media wrote as to "Five myths about child labour" (KweifioOkai, 2015) to determine whether child labour occurs in rich countries, and about "three women [having been] kept captive for 30 years" in South London (Butler \& Bowcott, 2013), revealing both the story of victims' discovery and their position prior to it. Serbian media feature stories about recruiting victims (especially women and children) that both highlight their personal experience and serve as a warning for those prone to being trafficked.

\section{Story: Framing and Manipulating the Fabula}

As the middle of the three layers of the narrative, a story consists of material "not different from that of either the text or the fabula", but "looked at from a certain, specific angle" (Bal, 2009, p. 91). To create the story, the fabula is "treated" and manipulated through inscription of a particular ideology (Bal, 2009, p. 92). ${ }^{7}$ In HT news texts, this "manipulation" of the fabula most notably takes form through creation/highlighting of news values $^{8}$ and focalization. In media studies, such promoting of "issue prioritization" and increasing of "issue accessibility" is referred to as "agenda setting" and "priming" (Johnson-Cartee, 2005, p. 25).9

${ }^{7} \mathrm{Bal}(2009$, p. 92) treats "manipulation" and "manipulated"in their original meaning of "handling, treatment, operation".

${ }^{8}$ In media studies, there is the question of the extent to which news values are intrinsic to an event. While Galtung and Ruge (1965, p. 71) maintain that an event "either possesses [news factors] or does not possess them", discursive analysis focuses not on how an event is selected as news, but how it is constructed as news (Bednarek \& Caple, 2017, p. 43; original emphasis).

${ }^{9}$ Johnson-Cartee $(2005$, p. 17) identifies three aspects of every mass-communicated news report's influence: agenda setting, priming, and framing. While the first two aspects show how news draw attention to some aspects of the story at the expense of others, framing 


\section{Newsworthiness, or How to Make a Story Publishable}

For Bal $(2009$, p. 91), the story is "the result of an ordering". Similarly, ordering or structuring is inherent in the process of creating a news story. In structuring news, the relevant elements of the fabula are tested against their newsworthiness - the list of criteria ${ }^{10}$ that contribute to the appeal of the news story to general audiences and deem the news story as one worth publishing. While it is true that various authors use different terms for news values, and that the exact number of identified criteria varies (cf. Brighton \& Foy, 2007, pp. 7-11), common factors are: oddity, proximity, timeliness, prominence, consonance, consequence, the number of those affected, negativity, and human interest.

\section{Oddity/Exceptional Quality}

As a news value that determines how uncommon the event is, oddity "is about establishing contrast with the expected" (Bednarek \& Caple, 2017, p. 66). The British news piece "Women for sale in Gatwick slave auctions" (Taylor, 2007) emphasizes this news value in its very headline. Since this value depends on the target audience and "their experience of the world" (Bednarek \& Caple, 2017, p. 66), an event may be construed as exceptional if it does not conform to stereotypes and statistical norms. This is seen in the following Serbian news texts, which translate into: "The greatest victims of HT are-construction workers!", "Proletariat in greater danger than sex workers", "[A] victim is also of masculine gender", "Men increasingly becoming victims of HT", and "Men are slaves too" (Dnevnik, 2014; Naše novine, 2014; Politika, 2009a, 2009b; Večernje novosti, 2007a). These texts indicate that the public expects typical victims of HT to be women forced into prostitution; that men (or construction workers/proletariat) are increasingly becoming victims of HT is unexpected.

An exaggerated aspect of this news value is shock value or scandal (cf. Brighton \& Foy, 2007, p. 8). This value is obvious in the UK example of

focuses on "how news content affects and influences news consumers" (Johnson-Cartee, 2005 , p. 25 ) and are discussed under "Ideological positioning". For a detailed overview of agenda setting, priming and framing theories, see Johnson-Cartee (2005, pp. 17-31).

${ }^{10}$ Bednarek and Caple (2012, p. 37), citing Bell (1991, pp. 180, 194, 320), refer to news values as both "qualities" and "criteria". For Bell (1991, p. 169), news values lead to "events being framed in a particular way". Analysing the process of creating and structuring news, Galtung and Ruge (1981, p. 60) state that "events become news to the extent they satisfy" the list of "conditions" known as news values. 
the Gatwick slave auctions, since the text not only depicts HT as a form of modern-day slavery, but also slavery happening out in the open, in a firstworld country. It is also blatantly emphasized in the following examples from Serbian press: "A girl sold for a laptop and €100", "A bride sold for $€ 1000$ ", and "A man sold his pregnant wife for $€ 1500$, then reported her kidnapped" (Blic, 2013b; Press, 2012; Večernje novosti, 2015a). Not only do these articles emphasize the unexpected behaviour, but also behaviour that is generally unacceptable according to social norms. By specifying the exact amount of money for which a human being is sold, the texts underline the shocking aspect of the event.

\section{Proximity}

According to Bednarek and Caple (2012, p. 42), what is newsworthy "usually concerns the country, region or city in which the news is published". In addition to geographical nearness, which extends to include neighbouring countries, proximity also refers to cultural closeness. Hence most news stories on HT published in both UK and Serbian media refer to events that occurred in these countries, or in countries perceived as culturally close to these countries. The UK press, for example, featured a story headlined "Scandal of the 'slaves' who pamper the nails of rich New Yorkers" (Usborne, 2005). The fact that the same sort of situation occurs in UK nail bars "employing" immigrant women also makes the story relevant to a UK audience. There is also a story about a "Baby 'sold' for $£ 6,500$ and a BMW" (The Daily Mail, 2015), which took place in France, a country geographically close to the UK. In Serbian media, there has also been a marked interest in the events occurring in/linked to the region of ex-Yugoslav countries and the Balkans (Croatia, Bosnia, Montenegro, Kosovo), which all belong to the same HT route. However, placing emphasis on the scandal or shock value is also enough to get a story published even if it happened at distant locations. The UK press featured the story of "A boy smuggled in a suitcase" (Badcock, 2015) taking place at the border between Morocco and the small Spanish territory of Ceuta, North Africa. In Serbian media, the story headlined "Moldova, the country of sex slavery" (Politika, 2007) claims that $10 \%$ of inhabitants of Moldova are victims of HT, that 400,000 young Moldavian women are victims of sex slavery, and that paedophiles from all over Europe fly in once a week to satisfy their appetites with the government's consent. The range of shocking details is enough to make the story appealing to the Serbian audience, although the factors of geographical and cultural proximity are here missing. 


\section{Timeliness}

Similarly, events that are recent or "temporally relevant to the reader" (Bednarek \& Caple, 2012, p. 42), in line with general journalistic emphasis on a " 24 hour news cycle", ${ }^{11}$ have precedence. This is especially true for what are known as hard news texts. ${ }^{12}$ Most texts published in both UK and Serbian print media feature events that have only just happened (e.g., recent arrests, court hearings, and announcements).

\section{Prominence}

News stories that feature celebrities, politicians, or even particular nations (perceived as geographically or culturally close to the relevant readership) are considered newsworthy. This is evident in the example from the UK press headlined "I was trafficked by Westminster abuse ring": "Vulnerable boys were trafficked from a children's home before being abused by 'very powerful' figures in a Westminster paedophile ring, a victim has claimed. [...] Once in the capital, they were molested by politicians and other Establishment figures..." (Marsden, 2015, my emphasis). In Serbian media, a lot of public attention-not only in Serbia but in the whole ex-Yugoslav region-went to a specific case of HT in which the Deputy Public Prosecutor in Montenegro was arrested for trafficking women (see Danas, 2004c; Večernje novosti, 2004b).

\section{Consonance}

Consonance refers to "the extent to which aspects of a story fit in with stereotypes" (Bednarek \& Caple, 2012, p. 56) about a nation, region, issue, person, and so on. This news value has been particularly emphasized in Serbian media, where the majority of HT news reports up to 2005 aimed to reinforce the stereotypes of victims being sex-trafficked girls from former Eastern bloc countries and Albanian nationals as traffickers. In British media, texts about foreign traffickers confirm the stereotype that $\mathrm{HT}$ is an imported problem caused by particular ethnic groups (e.g., traffickers from Hungary in "Sex trafficker facing prison", The Sun, 2015, or Romanian gypsy traffickers in "Baby is 'sold' for $£ 6,500$ and a BMW", The Daily Mail, 2015).

${ }^{11}$ Bednarek and Caple (2012, p. 20) define news cycle as "the time span between the publication/broadcast of a newspaper or news programme and the next edition".

${ }^{12}$ Hard news are "news associated with importance, significance, immediacy and relevance" (Zelizer \& Allan, 2010, p. 53), as opposed to soft or human interest news "that are not necessarily specific to a particular day, but provide background or a 'human interest' angle" (Fulton, 2005, p. 226). 


\section{Number/Consequence/Impact}

Space in the news will be more readily given to those HT stories that include/affect a considerable number of individuals, bear more consequence and have greater impact than others. The UK article " 348 held over Canadian child porn" (The Daily Telegraph, 2013) tells the readers that "More than 300 people including teachers and doctors have been arrested worldwide on child pornography charges after a Canadian-led investigation" (my emphasis). The newsworthiness is first created through shock, emphasizing the contrast between the publicly perceived trustworthiness of the professions of those arrested, and the criminal activity of child pornography. The fact that the criminal activity was widespread adds to the impact. Although in the following example voluntary migrant movements do not constitute an act of HT per se, the sheer number of people involved is what makes this UK story newsworthy: "Up to 700 migrants and refugees are feared to have drowned in the Mediterranean $[\ldots]$, making it the deadliest week this year [...]" (Squires, 2016, my emphasis). The UK article headlined "Domestic workers: 47 million people worldwide denied basic labour rights" (Kelly \& Scruton, 2015) also emphasizes the vast number of people affected, while simultaneously underlining the "worldwide" aspect of the case, and hence the universality of its consequence and impact. The following examples from Serbian press similarly emphasize the newsworthy value of "number": "Nearly 200,000 women caught in trafficking network" and "700,000 people sold around the world each year" (Danas, 2003; Glas javnosti, 2004b, my emphasis).

\section{Negativity}

In journalism, negativity is referred to as "the basic news value" (Bell, 1991, p. 156), since news stories "frequently concern 'bad' happenings" (Bednarek \& Caple, 2012, p. 57) such as conflicts, damage, or wars. Construing the value of negativity proved to be easy in HT news stories in both languages since most news texts on HT develop the conflict along the line of criminals vs. the police force/judicial system. In the UK press, such are the articles headlined "Britain to send intelligence officers to Sicily to "disrupt' human traffickers" (Watt et al. 2015), and "Reid out to crush 21 st-century slave trade" (Harrison, 2007). Also, the lead sentence of the article on New York nail bars states that "Andrew Cuomo, the Governor of New York, has ordered a crackdown on nail salons" (Usborne, 2005 ) in which "undocumented immigrant women" are treated as "slaves" (my emphasis). The Serbian press features the following examples: "Serbia 
to decisively fight HT", "Battle strategy to combat HT", and "exterminate modern slavery" (Kurir, 2012, my emphasis; Nedeljni telegraf, 2008; Politika, 2006). The choice of the expressions used heightens the tension created. However, the apparent conflict does not necessarily have to produce a negative effect, since the intended outcome of these actions (stopping criminals $/ \mathrm{HT}$ ) is not negative.

\section{Human Interest}

Human interest or personalization is the aspect emphasized in those news stories that "give a human face to the news" (Bednarek \& Caple, 2012, p. 44). As such, it is an aspect more common in soft news. See, for example, a UK press article headlined "Persecution and poverty driving the Gypsies of Romania to Britain" (Phillips, 2013). In Serbian media, such an example comes from a text on trafficking of babies in China (Politika, 2009d)—although lacking in proximity, the Serbian media still considered this story newsworthy because it presents a deeply touching issue with which the audience can sympathize irrespective of the country in which this audience lives.

\section{Focalization, Characters and Stereotypes}

As Bal (2009, p. 161) claims, whenever events are presented, they are presented from a certain point of view, which implies the "subjective nature of story-telling", even in journalism. Instead of "point of view", $\operatorname{Bal}(2009$, p. 162) uses the term "focalization", because it allows her to distinguish between "those who see and those who speak". ${ }^{13}$ The analysis of news texts on HT in both languages revealed that most news reports were prompted by noteworthy events, such as court proceedings, arrests, or government policy announcements. These events were commented on by representatives of the government, police, judiciary system, and other official establishments. Given that these commentators function as characters who see, that is, focalizers, focus is placed on the one-sided, "official" point of view. Such focalizers in the UK texts are: "Detective Superintendent Mark Ponting, of the Metropolitan Police", "Commander Sue Wilkinson, also of the Met", "Anti-slavery Commissioner Kevin Hyland”, "Mr Justice

${ }^{13} \mathrm{Bal}(2009$, p. 162) also acknowledges the following terms used in narrative theory to denote point of view: narrative perspective, narrative situation, narrative viewpoint, and narrative manner. 
Alan Moses", "prosecutor Karen Wiseman", "Home Secretary John Reid", "representatives of Scotland Yard", "officials who scanned a suitcase at the border", "the civil guard", and "the Pope" (Badcock, 2015; Leonard, 2001; Taylor, 2007; The Daily Mail, 2016; The Daily Star, 2008; The Daily Telegraph, 2015). As for the Serbian media, the focalizers featured are: the "Minister of Economy Predrag Bubalo", the "Minister of the Interior Ivica Dačić", the "national anti-trafficking coordinator", and the "United States Ambassador to Serbia Mary Warlick" (Dnevnik, 2009; Kurir, 2012; Politika, 2006, 2009c). These characters need not be individualized by their name, because it is their function that bears most relevance. Although both the official perspective and the fact that the news stories were prompted by establishment-related events might signal journalists' intention to provide an objective framework for the interpretation and analysis of the news stories, whether this objectivity is (or indeed, can be $)^{14}$ achieved is questionable. Favouring only one perspective signals partiality and the exclusion of alternative perspectives and frameworks of interpretation. My analysis thus contests the claim that, as "an autonomous sphere of social influence, which reports the facts honestly and evenhandedly to raise the consciousness of the audience and act as a force for social good" (Stockwell, 1999), news media are placing emphasis on objectivity.

Aside from focalizers, HT-related texts in both languages also feature characters who do not provide perspective. In the above-mentioned UK news texts, such characters are: "children forced into thieving", "youngsters who should be in school", "trafficking gangs", "organized criminals", "women being sold into prostitution", "women openly sold outside a café", "28 illegals", "evil lorry driver Perry Wacker", "illegal Chinese immigrants", "sex slave traffickers", "an eight-year old Ivorian boy", and "a 42-year-old man from Ivory Coast". In Serbian texts, such characters are: "Saša B. from Kačarevo", "Mile M., a theme-park owner from Aleksinac", "a 16-year old girl", and "B.M., a man from Novi Sad" (Informer, 2014; Kurir, 2013; Press, 2012; Večernje novosti, 2015a). These individuals are real people who have been turned into characters of a narrative and "attributed with social roles, personal qualities and actual utterances" (Fulton, 2005 , p. 237). In the interpretation of a HT news story, they stand as representatives of a social class, gender, or group (such as migrants, illegals, vulnerable women, innocent children, cunning traffickers). This reading

\footnotetext{
${ }^{14}$ For more on the impossibility of achieving objectivity, see Fulton, 2005, p. 231.
} 
within the suggested social, cultural, or political context produces stereotypical perception of participants in the HT process. ${ }^{15}$

Stereotyping of characters is especially prominent in those Serbian news texts that focus on ethnification of victims and traffickers. Prior to 2005, the ethnicity of HT victims and perpetrators identified in Serbian HT news was predominantly foreign. The majority of identified HT victims were women from Moldova, Bulgaria, Russia, and Ukraine, whereas the traffickers were especially prominently identified if Albanians (see also Dekić, 2003). This focus on the victims' ethnic origin contributes to existing prejudices, such as the one that trafficked women are naive foreigners from specific countries, and hence responsible for what befell them. This kind of portrayal also promotes victim blaming. As a result, victims of HT are stigmatized, marginalized, denied help and protection, and ultimately deprived of basic human rights.

In this same period (prior to 2005), trafficking as a phenomenon was rarely openly mentioned, obscuring the fact that HT occurs in Serbia and indicating the lack of interest to provide a deep analysis of the issue. Writing about her research into the Serbian news articles (printed from 1998 to $2001)$ related to women trafficking, Dekić (2003, p. 193) concludes that "an attitude was therefore created in the public mind that trafficking in women happens "somewhere else"". The same conclusion applies to the impression the media created in the period up to the year 2005. The year 2005 marks a watershed in media representation of HT in Serbia, after which point the majority of identified HT victims were Serbian nationals (in 2006-2007, 73.9\% Serbian victims; in 2010, 95\% Serbian victims-ASTRA, 2011).

\section{Archetypes and Angles}

In structuring a story-news stories included — event participants are construed as characters in such a way that both the roles they are given to play and the events themselves "fit in with archetypes of stories" (Bednarek \& Caple, 2012, p. 51). In this respect, in HT-related news stories in both languages it is possible to identify the archetypes of heroes, villains, plight, pursuit, rescue, crime, and punishment. Similarly, in media theory, Fulton (2005, pp. 233-234) writes about “'angles' that determine the narrative template" and "seem to be generic, almost universal, ways of ordering our world". In HT news stories in both languages, I identified the following archetypes or angles of representing HT.

\footnotetext{
${ }^{15}$ For more on characters as stereotypes in news narratives, see Fulton, 2005, p. 238.
} 


\section{A Criminal Act/Act of Organized Crime Story}

As the most frequent representation of HT in UK and Serbian print media, this angle treats HT as just another criminal chronicle entry which is interesting while it is current (i.e., "hot") news. News texts in both languages mostly focus on the issues of crime and punishment, presenting very limited information and lacking background information about, for example, details of the illegal operation being run. In the UK press, such examples include articles on a "Sex trafficker facing prison" (The Sun, 2015) in which the readers are told only that the trafficker and his gang face jail "for trafficking nearly 100 women to the UK to work in brothels" and the article "Man seized for "slavery", stating that "Le, of Deptford, South London, was arrested in Birmingham this week after an inquiry into alleged cannabis production" (The People, 2016). It is also added that "Le is also charged with arranging or facilitating the travel of another with a view to exploitation". However, no other information regarding the actual crime of HT is provided. In the Serbian press, criminal acts are reported by representatives of the police force, alleged perpetrators are identified by their first name and first letter of the surname (or initials only), while the victims are unnamed and identified by their age (Informer, 2014; Kurir, 2013; Press, 2012; Večernje novosti, 2015a).

In HT news in both languages there is no investigative approach to the issue, nor an analysis of causes, consequences, or the full scale of the problem. It is reasonable to conclude that in some of the texts at least (e.g., in the UK text on illegal immigrants on cannabis farms in the UK), a shift of focus might change public perception, perhaps through including the perspective of HT as a crime against human rights. In Serbian media, some of the questions that should have been more prominently analysed are, for example, the adequacy of punishment for the perpetrators and the suitability of laws under which they are prosecuted. The introduction of antiHT laws in Serbia, as a non-EU country, has been slow and, as a result, anti-HT efforts are still marred by a very slow or inadequate implementation of the laws in the field. ${ }^{16}$ Texts that draw attention to the inadequacy

\footnotetext{
${ }^{16}$ According to the Human Trafficking Manual for Journalists (issued by ASTRA—a Serbian non-profit anti-HT organization, and OSCE Mission to Serbia), "the state authorities of Serbia and Montenegro placed the problem of HT on the political agenda after the change of political climate in 2000. The US State Department, in its 2001 Trafficking in Persons Report, classified the Republic of Serbia into Tier 3, assessing that it did not fulfil minimum standards in combating HT. One year later, Serbia passed into Tier 2. [...] HT was introduced as a criminal offence into the Criminal Law of Serbia-Article 111b-in April
} 
of laws and, subsequently, punishment, are rare and do not offer any incentive for action, nor do they envisage any solution to the problem. If provided, the answers to these questions might further illustrate the efficacy of the anti-trafficking efforts, pinpoint the weak spots of the legislative foundation, and ultimately lead to its improvement.

\section{A Lucrative Business}

Since the explicit mentioning of money is bound to raise interest and provide both shock value and impact value, this is an angle readily taken when representing HT in the British and Serbian press. UK print news state that "[p]eople are making a lot of money. In sexual exploitation, someone can make 1 million pounds a year out of 10 women", or that "One woman could fetch between 6,000 and 8,000 pounds. She could then earn her buyer 800 pounds a day" (Taylor, 2007; The Daily Telegraph, 2015). In Serbian media, such information is placed in the headlines: "People traffickers in Serbia earning millions of euros from prostitution", "People traffickers earn slightly less than drug lords", "Jočić: HT fetches as much as 13 billion dollars a year", "60 billion euro per year in HT" (Blic, 2011; Dnevnik, 2007; Glas javnosti, 2007; Press, 2009). Again, what is evident is the problem of perspective-the focus is not on the victims, but on the business aspect of the crime. Additionally, in Serbian media, HT is presented as a lucrative business with minimal risks due to the abovementioned gaps in the legal system.

\section{Sensational News}

The third angle taken with HT representation is that of the sensationalist coverage of the issue. This is especially evident in Serbian media, in which all the gory and scandalous details of women trafficking are emphasized, as in the aforementioned cases of underage victims, victims trafficked by the members of their family, or victims sold into prostitution for ridiculous amounts of money and/or other material possessions. These articles also focus on methods of coercion, underlining the brutality of these crimes but also convincing the public that the women in question are indeed

2003. [... O On 1 January 2006, the new Criminal Code of Serbia came into force. In Article 388 , it introduced some novelties into the definition of human trafficking and new penal provisions for this offence, distinguishing it clearly from people smuggling”. For more on the legislative and institutional framework for tackling HT in Serbia in, see the Human Trafficking Manual for Journalists (2008). 
victims, as if otherwise they would not be believed, for various cultural reasons. This is indicative of victims' perceived position, credibility, and ultimately their basic human rights. Similarly, the UK press featured an article on a human traffickers' camp ("the makeshift jail, made of bamboo and barbed wire" "that may have held up to 300 people") discovered in the Malaysian jungle (Freeman, 2015). The camp was equipped with cages that held prisoners, and the camping ground was scattered with human remains, "including a jaw bone". Although the torturing methods of these human traffickers are repulsive and certainly draw attention to the mechanisms used by the trafficking syndicates to force their victims into submission, there is also no doubt that the newspaper article focuses on the sensationalist approach in its choice of perspective and journalistic angle. Foregrounding shocking aspects is a simplistic approach that pushes the real causes of HT to the background.

\section{TeXt And Narration}

\section{Text Structure}

As Bednarek and Caple (2012, p. 96) posit, a typical news text consists of three parts: headline, intro/lead, and body/lead development. The headline and intro/lead serve to "frame the event, summarize the story and attract readers", also construing newsworthiness (Bednarek \& Caple, 2012, pp. 96-97). ${ }^{17}$ A good example of how the choice of headlines draws attention to particular aspects of the event and implies ideological positioning is found in the Serbian corpus. On 26 March 2013, three newspapers published stories regarding the same event, a 16-year-old girl being forced into prostitution by the gang of four for one month (Blic, 2013a; Informer, 2013; Kurir, 2013). All three headlines emphasize the force used against the victim. Other than that, the journalists chose to emphasize different aspects of this crime. In the articles headlined "They forced a little girl into prostitution!" and "A child forced into prostitution!", both the act of forced prostitution and the age of the victim are highlighted, emphasising the story's shock value. The sensationalist aspect in both articles is further enhanced by the exclamation mark. One headline, however, opts for disclosing the sex of the victim ("little girl"), while the

\footnotetext{
${ }^{17}$ Bednarek and Caple (2012, p. 97) here also acknowledge the fact that the headline and intro/lead are frequently seen as "one unit" called "abstract" or "nucleus".
} 
other focuses on the fact that the victim was a child, not stating the sex, thus removing any association with sexual activities (as completely inconceivable for children in general) and implying the damage done to the childhood innocence. The headline "A teenager force-solicited for a month" presents the victim as significantly older ("a teenager") and thus the possibility of sexual activities is not automatically excluded for the victim, which might make the criminal act slightly less grave (or at least slightly less shocking) in the eyes of the readership. The focus is, however, placed on the length of the molestation period ("a month"). While the previous two headlines are given in the passive voice, placing focus on the victim and not the perpetrators, in the third headline the guilt of perpetrators (and not the suffering of the victim) is stressed.

In standard journalism, events are not presented chronologically. Instead, information about these events is ordered according to its significance, following the inverted pyramid structure (Bednarek \& Caple, 2012 , p. 100; Fulton, 2005, p. 228): the news lead provides a summary of the event, followed by crucial details and quotations, whereas the least important details are placed at the end of the text. In this respect, Meilby (1996, p. 254) distinguishes between four main groups of information according to their dissemination: introduction (new, important information), background (provides perspective for the information), documentation (usually quotes), and filling (information that could be left out). News stories on HT in both languages generally follow this organizing principle, with one crucial exception-contextual information, necessary to evaluate the news, is placed at the very end of the story. One such example is found the UK text headlined "Children forced into Oliver Twist thieving" (The Daily Telegraph, 2015), with the following closing remark: "The Home Office estimated in December that there were up to 13,000 victims in the UK, and Mr Hyland said there were 151 convictions last year". This final sentence, instead of containing "filler" information, provides additional context for interpretation (through contrasting the number of victims to the number of convictions), and proves necessary for the intended meaning (implicitly showing the lack of success when responding to HT). In the Serbian article on "Men increasingly becoming victims of HT" (Politika, 2009b), the text presents a study done by the Victimological Society of Serbia and provides information on the number of male victims identified in one year (407 victims in 2003). The closing remark emphasizes the lack 
of a state registry of the male trafficking cases and of a support network for the victims, while drawing attention to the misconstrued public image of a typical trafficking victim as being female. The closing part of the text, thus, provides a crucial insight into the problem and encourages the wider definition of both $\mathrm{HT}$ and its victim profile.

\section{Levels of Narration}

Both UK and Serbian articles on HT typically feature two levels of narration: the frame/primary text (commonly a testimony, commentary, or report made by a primary source of information) and the embedded text (featuring the act of trafficking and/or criminal acts committed by the trafficked people). ${ }^{18}$ A UK press example headlined "Girl 'passed round 60 men in sex ring"" (Elsk, 2015) brings the report on a court hearing of "eleven men on trial" accused of "multiple rape of a child under 13 , child prostitution" and other offences related to the crime. While the primary text features a statement by "Oliver Saxby, QC, for the prosecution" (as an official source) on the trial itself, the embedded text brings details of the crime (the abuse of the child and her friend by 60 men in sex abuse gang, the targeting, grooming, drugging and molestation details). Such division on the level of narration mirrors the choice of focalization on the level of the story, since the focalizers are "placed" within the primary text, while the characters are positioned within the embedded text. In the Serbian article about the sex trafficking of a teenage girl (Blic, 2013a), the frame text features the police arrest of four people suspected of this crime and a one-month custody they received at the initial court hearing. The embedded text brings the story of the crime-the beatings, threats and soliciting the victim had to endure. What this suggests about the text's ideological viewpoint is that the focus is on the consequences of the crime and on those who have the power to deal with those consequences (the police force, judicial system, government institutions), not on the roots of the crime and the analysis of those circumstances that led to victims being vulnerable in the first place.

\footnotetext{
${ }^{18} \mathrm{Bal}(2009$, p. 73$)$ refers to the primary text as "the narrator's text" and to the embedded text as "the actor's text", stating that their hierarchical position is indicated "by the fundamental principle of level".
} 


\section{Genve}

McNair (1998, pp. 9-10) distinguishes between five basic forms of journalistic output: news report/fact report, feature article (equivalent to the documentary; in-depth reportage/analysis), commentary/column (authoritative viewpoint on an issue), interview, and editorial (a newspaper/periodical that "speaks out" in its "public voice"). The most frequent, and indeed dominant, journalistic genre in articles on HT in both languages is that of news report, which reduces the issue of HT to several lines of fact-oriented announcements that do not portray HT in any depth. The least frequently seen are pieces of investigative journalism that would investigate factors leading to and governing the process of HT. Some of these factors might include economic, political, and social issues, such as: loss of jobs, poverty, existential crises, lack of laws, poor implementation of the laws, violence against women, lack of human rights, and general criminal activities and tendencies. On the other hand, HT might be linked to region-specific events: wars, general instability, foreign activities and influences, and forced or voluntary migration. Investigation into these roots, however, is missing from the texts on HT in both languages. This conclusion is in accordance with the general tendency in standard journalism, which states that economic factors and market forces direct the present-day journalism towards pure fact reports and away from investigative journalism as a not so cost-efficient genre (cf. Fulton, 2005, pp. 224-225).

\section{Ideological Positioning}

As Soderlund (2002, p. 441) indicates, news reports present "a site of cultural production that operates according to institutional and professional rules and paradigms and within dominant political ideologies". While the previous aspects of analysis show the workings of these rules and paradigms of the journalistic profession when creating news texts on HT, and thus answer the question of how the intended meaning is created and how, subsequently, the ideological position underlying such creation is indicated, this section shows what this ideological position is and why it is present in the first place.

McNair (1998, p. 5) maintains that there is no such thing as creating news without making deliberate choices when selecting and contextualizing facts. Hence, reality is never simply reflected in the news accounts, 
nor are journalists simply independent and objective recorders of events (Bird \& Dardenne 1988, p. 66; Johnson-Cartee, 2005, p. 157). Since placing emphasis and creating focus implies a certain standpoint, the process of news construction necessarily creates bias and promotes an agenda. In questioning the agenda when creating a story we, as readers, are conducting what Walter Fisher (1970, p. 131) refers to as a "motive analysis". According to him, an author always has a reason, or reasons, for putting a narrative before an audience. These reasons, or motives, not only determine the content of the narrative, but also the manner of its construction and delivery. The content is never devoid of "an attitude about that content" (Fisher, 1970, p. 132). Thus, every narrative "expresses a theme or thesis, an inference of judgment, which is to be preferred above any other proposition or proposal that relates to its subject matter" (Fisher, 1970 , p. 131). In passing this judgement, “journalism, therefore, like any other narrative which is the work of human agency" becomes "essentially ideological-a communicative vehicle for the transmission to an audience not just of facts but of the assumptions, beliefs and values of its maker(s), drawn from and expressive of a particular world-view" (McNair, 1998, p. 6).

In news media texts in both languages, the framing of HT-as a social, political, and public issue-prompts a particular response both on the part of the public and that of governmental institutions. Framing of HT as a criminal activity draws attention away from the economic, political, and social roots of the problem and reduces a very complex issue to a simple one that can be tackled through the application of a range of policing and law enforcement measures. Writing about UN anti-trafficking policy in Bosnia and Herzegovina, Vandenberg (2007, p. 92) questions the effect this type of media coverage has on HT, envisaging increased policing as the response to the rise in media coverage of trafficking activities. According to her, aggressive policing might produce greater negative consequences for the trafficked individuals than for the traffickers.

Ethnification of characters in reports on HT in both languages creates a misguided impression that HT is an imported problem, legitimizes calls for strict immigration laws, and creates tension between the domestic population and immigrants. Media prioritization of sex trafficking and women trafficking over other types of trafficking promotes the gender aspect of the problem and contributes to the further victimization of women and forced sex workers, establishing a cause and effect link between prostitution and trafficking (Chang \& Kim, 2007, p. 3). Additionally, it creates 
the need for strict anti-prostitution laws, which again diverts attention from investigation into the broader phenomenon of trafficking and identification of "factors that facilitate trafficking, such as poverty, discrimination, and civil and political unrest" (Chang \& Kim, 2007, p. 3 ) of certain regions. Unlike the UK, which serves as a destination country, Serbia's role in human trafficking is currently three-fold: it serves as a country of origin (mostly for women trafficked into Bosnia, Kosovo, Macedonia, West Europe), a destination country, and a key transit country in the Balkans (for victims trafficked into Italy, Spain, and France via Bosnia, or to the Near East via Kosovo and Macedonia). Although Serbian news media emphasize the need to investigate the factors that make victims, especially women, vulnerable to traffickers, this investigation is missing from the news texts. The issues such as poor economic situation (in the post-Soviet and post-Eastern bloc countries), high tolerance of violence against women, militarization of the regions, and great social and political disturbance of the 1990s and 2000s, appear to be problems better left untouched.

All the measures and actions devised or called for by the framing of HT focus on its effects, not causes. In this way, in Kempadoo's words (2005, p. xiv), "neoliberal economic interests of corporations, multilateral agencies, policy experts and national governments" remain protected, "rather than those of the world's working and poor people".

\section{CONCLUSION}

The treatment of narrative elements and narrative structure determines the focus of the news media texts. Most articles on HT, in both languages, place the primary focus on arrests, court proceedings, and government announcements, with a secondary focus on the act of trafficking itself. The media's reliance on official sources leads to bureaucratization of the news on HT and necessarily implies the ideological position taken by news agencies. Alternative points of view, such as those belonging to the academics or activists in the field, are either completely excluded or awarded a far less prominent position. This minimizes the role and the influence other sectors might have in producing legislative acts and public policies relevant for dealing with HT and steers the public towards establishmentprovided viewpoints. Additionally, the media framing of HT and insistence on the few chosen paradigms seriously obstructs the public perception of the problem and limits both the interest and the influence 
that more extensive public debate might provide. The public agenda on HT shaped in this way by the print news media, both in UK and Serbia, suggests strong inclination towards retaining the status quo of political power relations and economic interests.

\section{REFERENCES}

ASTRA. (2008). Human trafficking manual for journalists. Belgrade: ASTRA.

ASTRA. (2011). Human trafficking in the Republic of Serbia: Report for the period 2000-2010. Belgrade: ASTRA.

Badcock, J. (2015, May 9). Excess baggage: Boy smuggled in a suitcase. The Daily Telegraph, [no pagination].

Bal, M. (2009). Narratology: Introduction to the theory of narrative. ( $3^{\text {rd }}$ ed.). Toronto: University of Toronto Press.

Bednarek, M., \& Caple, H. (2012). News discourse. London: Continuum.

Bednarek, M., \& Caple, H. (2017). The discourse of news values: How news organizations create newsworthiness. New York: Oxford University Press.

Bird, S. E., \& Dardenne, R. W. (1988). Myth, chronicle and story: Exploring the narrative qualities of news. In J. W. Carey (ed.), Media, myth, and narratives: Television and the press (pp. 67-86). London: Sage.

Blic. (2004, August 8). Trgovina ljudima u Srbiji, [no pagination].

Blic. (2011, July 24). Trgovci ljudima po zaradi posle rasturača narkotika, [no pagination].

Blic. (2013a, March 26). Tinejdžerku mesec dana silom podvodili, [no pagination].

Blic. (2013b, September 17). Prodao mladu za 1.000 evra, [no pagination].

Butler, P., \& Bowcott, O. (2013, November 22). Call for help was first step to freedom. The Guardian, p. 3.

Chang, G., \& Kim, K. (2007). Reconceptualizing approaches to human trafficking: New directions and perspectives from the field(s). Stanford Journal of Civil Rights and Civil Liberties, 3, 317.

Clark, A. (2001, April 21). Slavery summit: Confectioners pledge to halt cocoa farm abuse. The Guardian, [no pagination].

Conboy, M. (2007). The language of the news. New York: Routledge.

Danas. (2003, September 23). Oko 200.000 žena u švercerskoj mreži, [no pagination].

Danas. (2004a, January 29). Godišnje od 700 hiljada do dva miliona žrtava, [no pagination].

Danas. (2004b, May 8). Tri godine zatvora za šverc ljudi, [no pagination].

Danas. (2004c, December 1). Uvredljiv tretman žrtve, [no pagination].

Danas. (2005, November 4). Godišnje se preprodaje dva do četiri miliona ljudi, [no pagination]. 
Danas. (2015, March 4). Osuđeni za trgovinu ljudima, [no pagination].

Dekić, S. (2003). Sex, slavery and politics: Representations of trafficked women in the Serbian media. Journal of Canadian Women's Studies, 22(3/4), 192-200.

Dnevnik. (2007, October 19). Jočić: Od trgovine ljudima godišnje i do 13 milijardi dolara, [no pagination].

Dnevnik. (2009, October 19). Kad “momci” nestaju, robovlasnici propadaju, [no pagination].

Dnevnik. (2014, August 1). Proleteri ugroženiji nego seksualne radnice, [no pagination].

Elsk, S. (2015, May 19). Girl 'passed round 60 men in sex ring'. The Times, p. 20.

Fearn, H. (2015, May 16). 'Trafficked' Briton to lodge drugs death-sentence appeal. The Independent, p. 16.

Fisher, W. R. (1970). A motive view of communication. Quarterly Journal of Speech, 56, 131-139.

Freeman, C. (2015, May 27). Cages found at jungle traffickers' camp. The Daily Telegraph, p. 16.

Fulton, H. (2005). Introduction: The power of narrative. In H. Fulton, R. Huisman, J. Murphet, \& A. Dunn (eds.), Narrative and media (pp. 1-8). Cambridge: Cambridge University Press.

Galtung, J., \& Ruge, M. (1981). Structuring and selecting news. In S. Cohen \& J. Young (eds.), The manufacture of news (pp. 57-72). London: Constable.

Glas javnosti. (2004a, August 4). Kako se zaštititi od trgovaca ljudima, [no pagination].

Glas javnosti. (2004b, November 2). U svetu godišnje oko 700.000 prodatih ljudi, [no pagination].

Glas javnosti. (2007, November 11). Obrne se i 60 milijardi evra godišnje, [no pagination].

Harrison, D. (2007, March 18). Reid out to crush 21st-century slave trade. The Daily Telegraph, [no pagination].

Informer. (2013, March 26). Terali devojčicu na prostituciju! [no pagination].

Informer. (2014, March 15). Vlasnik luna-parka 4 godine imao roba, [no pagination].

Jahn, M. (2005). Narratology: A guide to the theory of narrative. Cologne: University of Cologne.

Johnson-Cartee, K. S. (2005). News narratives and news framing: Constructing political reality. Lanham: Rowman \& Littlefield.

Kelly, A., \& Scruton, P. (2015, April 2). Domestic workers: 47 million people worldwide denied basic labour rights. The Guardian, [no pagination].

Kempadoo, K. (2005). Introduction: From moral panic to global justice: Changing perspectives on trafficking. In K. Kempadoo (ed.), Trafficking and prostitution reconsidered: New perspectives on migration, sex work, and human rights (pp. vii-xxxiv). Boulder: Paradigm Publishers. 
Kurir. (2012, June 26). Vorlik: iskorenite savremeno ropstvo, [no pagination].

Kurir. (2013, March 26). Dete terali na prostituciju! [no pagination].

Kweifio-Okai, C. (2015, June 12). Five myths about child labour. The Guardian, [no pagination].

Leonard, T. (2001, April 6). 14 years for trucker who left 58 to die. The Daily Star, p. 8.

Marsden, S. (2015, April 7). I was trafficked by Westminster sex abuse ring. The Daily Mail, p. 10.

McNair, B. (1998). The sociology of journalism. London: Arnold.

Meilby, M. (1996). Journalistikkens grundtrin. Arhus: Forlaget Ajour. Quoted in: E. Grunwald (2005). "Narrative Norms in Written News". Nordicom Review, 26(1), 63-79.

Naše novine. (2014, August 5). Najveće žrtve trgovine ljudima su—građevinci! [no pagination].

Nedeljni telegraf. (2008, September 24). Srbija u odlučnoj borbi protiv trgovine ljudima, [no pagination].

Phillips, M. (2013, November 2). Persecution and poverty driving gypsies of Romania to Britain. The Sun, pp. 44-45.

Politika. (2004, June 4). Stop trgovini i krijumčarenju ljudi, [no pagination].

Politika. (2006, December 8). Strategija borbe protiv trgovine ljudima, [no pagination].

Politika. (2007, August 21). Moldavija, zemlja seksualnog ropstva, [no pagination].

Politika. (2009a, January 5). Žrtva je i muškog roda, [no pagination].

Politika. (2009b, September 24). Muškarci sve više žrtve trgovine ljudima, [no pagination].

Politika. (2009c, October 19). Dan borbe protiv trgovine ljudima, [no pagination].

Politika. (2009d, October 29). Hajka na otmičare, [no pagination].

Pravda. (2010, October 18). Filmom protiv organizovanog kriminala, [no pagination].

Pregled. (2011, July 18). Domaći državljani na meti, [no pagination].

Press. (2009, July 27). Tužilac: Trgovci ljudima u Srbiji zarađuju milione evra na prostituciji, [no pagination].

Press. (2012, September 26). Prodao trudnu ženu za 1.500 evra, pa prijavio da je oteta, [no pagination].

Rankin, J. (2016, May 19). Human traffickers 'using migration crisis' to force more people into slavery. The Guardian, [no pagination].

Smith, H. (2015, August 20). UK police deployed to Calais to tackle peopletrafficking gangs, p. 19.

Soderlund, G. (2002). Covering urban vice: The New York Times, "White slavery," and the construction of journalistic knowledge. Critical Studies in Media Communication, 19, 438-460. 
Squires, N. (2016, May 30). Hundreds of migrants drown in deadliest week in Mediterranean this year. The Daily Telegraph, p. 16.

Stockwell, S. (1999). Beyond the fourth estate: Democracy, deliberation and journalism theory. Australian Journalism Review, 21(1), 38.

Tannen, D. (1993). Framing in discourse. Oxford: Oxford University Press.

Taylor, B. (2007, March 8). Women for sale in the Gatwick slave auctions. The Daily Mail, p. 41.

The Daily Mail. (2015, April 8). Baby is 'sold' for $£ 6,500$ and a BMW, p. 26.

The Daily Mail. (2016, May 30). Pope slams 'blood sucker' bosses, p. 33.

The Daily Star. (2008, March 8). Halt this Evil Trade, p. 6.

The Daily Star. (2016, May 23). 28 illegals in a lorry, p. 2.

The Daily Telegraph. (2013, November 13). 348 held over Canadian child porn, p. 22.

The Daily Telegraph. (2015, June 1). Children forced into Oliver Twist thieving, warns anti-slavery chief, p. 11.

The Guardian. (2015, June 27). Man charged with human trafficking after raid rescues Romanian woman, [no pagination].

The People. (2016, May 29). Man seized for 'slavery', p. 9.

The Sun. (2015, July 17). Sex trafficker facing prison, p. 14.

The Times. (2007, March 24). Police fear Olympics will lure sex slave traffickers, p. 15.

Usborne, D. (2005, May 12). Scandal of the 'slaves' who pamper the nails of rich New Yorkers. The Independent, p. 24.

Vandenberg, M. E. (2007). Peacekeeping and rule breaking: United Nations antitrafficking policy in Bosnia and Herzegovina. In H. Richard Friman \& S. Reich (eds.), Human trafficking, buman security, and the Balkans (pp. 81-95). Pittsburgh: University of Pittsburgh Press.

Večernje novosti. (2004a, October 20). Svedočenje bez okrivljenih, [no pagination].

Večernje novosti. (2004b, December 1). Vređaju Moldavku, [no pagination].

Večernje novosti. (2007a, November 10). I muškarci roblje, [no pagination].

Večernje novosti. (2007b, November 25). Bilo jednom na Balkanu, [no pagination].

Večernje novosti. (2015a, April 16). Prodao devojku za laptop i 100€, [no pagination].

Večernje novosti. (2015b, June 2). Uhapšeno 13 osoba, [no pagination].

Watt, N., Travis, A., \& Mason, R. (2015, June 17). Britain to send intelligence officers to Sicily to 'disrupt' human traffickers, [no pagination].

Zelizer, B., \& Allan, S. (2010). Keywords in news and journalism studies. Maidenhead: Open University Press. 
Open Access This chapter is licensed under the terms of the Creative Commons Attribution 4.0 International License (http://creativecommons.org/licenses/ by $/ 4.0 /$ ), which permits use, sharing, adaptation, distribution and reproduction in any medium or format, as long as you give appropriate credit to the original author(s) and the source, provide a link to the Creative Commons license and indicate if changes were made.

The images or other third party material in this chapter are included in the chapter's Creative Commons license, unless indicated otherwise in a credit line to the material. If material is not included in the chapter's Creative Commons license and your intended use is not permitted by statutory regulation or exceeds the permitted use, you will need to obtain permission directly from the copyright holder.

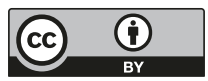

